\title{
Green Human Resource Management in Egyptian Hotels: Practices and Barriers
}

\author{
Ahmed E. Sobaih \\ Hotel Management Department, Future Academy, Cairo, Egypt
}

\begin{abstract}
Green Human Resource Management (GHRM) refers to usage of human resource rules to support the sustainable use of property resources and to guarantee environmental sustainability. The practices of GHRM include planning, green job analysis and design, green recruitment and selection, green induction, training and development, green performance appraisal, green reward management, green employee discipline management and green employee relations. This research aims to identify the extent to which Egyptian hotels adopt GHRM practices and the barriers of implementation. To achieve this aim, a total of 347 self-administrated questionnaires were distributed to a random sample of hotel human resource managers in Red Sea Region. Among the questionnaires returned, 303 were useable ones, representing a response rate of $87.3 \%$. The results showed that Egyptian hotels in Red Sea Region do not apply the GHRM practices due to a number of barriers related to management and employees facing their implementations. There are some implications for both academics and hoteliers.
\end{abstract}

Keywords: Green human resource management (GHRM); green human resource practices; GHRM barriers; Egyptian hotels

\section{Introduction}

The hotel industry faces big pressures to give massive care to the conservation of the environment by introducing a service and product that harmless to the environment and safer for hotel guests (Yusoff et al., 2018). On the other hand, several studies (e.g. Goessling et al., 2005; Bohdanowicz 2006; Brun-smith et al., 2015) confirmed that the traditional hotel practices are against the preservation of environment and harmful too. It was also argued that the hospitality sector releases on daily basis around $20.6 \mathrm{~kg}$ of carbon dioxide, a waste per guest per day at least one $\mathrm{kg}$ and 218 gallons of water per day per occupied room in the standard hotel (Bohdanowicz 2006; Brun-smith et al., 2015). Consequently, due the tremendous harmful of environment issue there are increasing forces to give more attention to environment concerns (Erdogan and Brais, 2007). 
Researches has confirmed that management of human resource is the basic to achieve the best ecological management (e.g. Daily and Huang 2001; Jackson et al., 2011). In that sense, human resource management (HRM) can smooth the effective formulization and accomplishment of environmental management by stratifying practices such as selection, performance appraisal, and training with environmental objectives (Jabbour, 2013). Therefore, it is required to put together green concepts into HRM in order to be GHRM (Mishra et al., 2014). Given this, Yusoff et al., (2018) confirmed that GHRM practices is the best strategy of environmental conservation programs and it provides a primary framework that allows organizations to oversee impacts of the environment. On contrary, the obtainable literature shows that there has been growing a care on green marketing, green finance and green management. Nonetheless, GHRM practices and barriers for implementations are relatively diverse and fractional (Renwick et al., 2013). This research adds to the academic literature and bridges a gap in knowledge in relation to GHRM in the hotel industry.

\section{Literature Review}

Tourism and environment have a close relationship as Mathieson and Wall (1982) argued that natural environment is a center feature of tourism industry. Regarding to hospitality industry, it is one of the largest industry in the world, consumes an extensive amount of natural resources, and produce an immeasurable amount of waste and pollution (Bohdanowicz, 2006). In that context many studies (e.g. Vikneswaranand Anantharajah,2012; MolinaAzorínetal., 2009; Rahman et al., 2012) showed that the hotel industry managers realized that they should be changed to be green operators and apply the sustainability managements.

\section{A. The Concept of Green Human Resource Management (GHRM)}

Green company refer to corporations that offer environmentally friendly services and products, using of renewable energy, efficient using of resources, reducing all negative impact on the environment by using green activities (Jafri, 2012). In that sense, Ramnus (2002) stated that green activities are defined as the activities that guide an organization to reduce its harmful environmental impacts and conserve natural resources. On the other hand, the main role of workforce is to achieve the organizational objectives by developing and implementing business strategies. Therefore, organization should ensure that it has the talented and skilled people to achieve its green policies (Phillips, 2007). According to Gerhart et al., (2000) effective achievement of green plans depends on whether organization employee green or not. 
GHRM is one side of green management aims to preserve the environmental balance (Goswami and Ranjan, 2015). GHRM aims to conserve the environment and apply the environmental sustainability (Deepika, 2016; Javed and Cheema,2017). GHRM refers to all actions or activities involved in development and implementation of a system that aims to make employee green in order to achieve environmental sustainability goals (Renwick et al., 2015). Mampra (2013) determined GHRM as the use of HRM pursuit to support environmentalism and promote sustainable use of organization resources. To that end, Owino and Kwasira (2016) added that GHRM practices like job descriptions, selections, training, performance and evaluation.

Dutta (2012) confirmed that GHRM practices are the best approach that help the company by making a 'green employee' who realizes the environmental performance in the workplace by stressing on green employing, green training and development, green reward and beneficent the companies' human capital. According to Opatha and Arulrajah, (2014) human resource planning, recruitment and selection, training and development, performance appraisal, rewards management and human relations which are HRM main practices are deemed as instruments for aligning staff with establishment's environmental policies.

\section{B. The Importance of GHRM}

Earlier, the achieved profit for any organization was the measure of the organizational success, but this no longer is the target only. Recently, it is essential to incorporate organization's aims to obtain financial earnings with the goals of ecological management and sustainability (Ullah, 2017).

Green organizations have several practices and gaining advantages by applying GHRM, such as maximizing the profitability by reducing wastes, recycling and reusing of materials, enhancing the property image, attracting and retaining customers who are interested in environment conservation (Haden et al., 2009). According to Ashraf et al., (2015) hotels that applied GHRM practices are gaining many advantages than those that do not perform these practices. Nonetheless, there are a many benefit generated based on GHRM implementation for hotels as well as for employees. For the hotel, it has a sustainable competitive advantage and better financial performance (Fayyazi et al., 2015; Ayeswarya, 2017).

Garg (2014) reported that GHRM could be considered as a tool in attracting guests who are concerned in the environment, and sustain environmental activities as well as ensuring employee satisfaction. Additionally, Sheopuri and Sheopuri (2015) added that GHRM resulted in improving guest confidence in hotel, improving the hotel's situation in the market and 
reducing the environment harmful affection. Hotel employees also are gaining a benefit based on GHRM practices such as reducing staff turnover and improving the relationships between hotel and their employees (Deshwall, 2015). Likhitkar and Verma (2017) added other benefits like increasing loyalty of hotel employees and the productivity too.

\section{GHRM Practices}

As discussed earlier, GHRM refer to all practices of HRM aiming to make employee of organization green to achieve organization's environmental goals and contributions to sustainability of environment (Renwick, 2008). In addition, Mehta and Chugan (2015) stated that organizations are embracing GHRM practices such as green recruitment, training, appraisal and reward management. This has helped to create and promote a sustainable green environment in the organization. Similarly, Cherian and Jacob (2012) in their study recognized that recruitment, training, employee motivation, and rewards are important human scopes that contribute to the improvement in employee implementation of GHRM principles.

\section{Planning for GHRM}

The implementation of GHRM begins early even before employee selection, the concept of GHRM started with green planning. According to Jackson et al., (2011) planning of GHRM is to confirm that the hotel obtains and retains quantity and quality of candidates it needs to achieve its environmental goals. In that sense, Opatha (2013) confirmed that by using GHRM planning, the hotel will be able to develop resourcing strategies through forecasting types and numbers of personnel required to execute the organization's environmental management practices and deciding policies to meet the expected demand for environmental activities. The same author added that the environmental management initiatives might require some new positions and specific set of skills.

\section{Green job analysis and design}

For applying GHRM, job analysis included job descriptions and job specification that should have a green perspective. According to Renwick (2008), the job specification for each job should contain the required skills, knowledge and abilities needed to achieve the environment responsibilities. Moreover, the job description should also include environmental tasks. Furthermore, some hotels use teamwork and cross-functional teams as job techniques to handle the environmental concerns of the organization (Govindarajulu and Daily, 2004; Jabbour et al., 2010). In that sense, Arulrajah et al., (2016) added that many hotels have made a specific job title 
that is responsible for the co-ordination of different aspects of environmental management.

\section{Green recruitment and selection}

According to Ramnus (2002), there are two choices for effective green employees' recruitment, whether to focus on green recruitment of the expected employee, or to provide existing employees with required environmental concern training. The same author added that the first choice, i.e., is to focus on green recruitment of the expected employee is more practical and lower cost than the second choice, i.e., to provide existing employees with essential environmental training.

Process of attracting green candidates for job vacancies, job advertisements should express certain environmental values (e.g. be a part of the green team). While some organizations prefer to recruit the new employees, who have competencies and attitudes to participate in corporate environmental management initiatives too (Renwick et al.,2013). Moreover, selection criteria should include containing environmental concern and interest (Renwick et al., 2015). In that sense, Revill (2000) and Opatha (2013) stated that during candidate's interview or evaluation for selection, processes and testing should have environment-related questions.

\section{Green induction, training and development}

Generally, the induction is aiming to make the new candidates are familiar with hotel atmosphere. Green induction process according to Arulrajah et al., (2016) can be process by two approaches; first approach is general green induction once the candidates are hired through providing an elementary knowledge about the environmental management policy and functions. Second approach is job specific green induction by enroll new candidates about environmental orientation programs particular to their jobs. To that end, the green induction is aiming to make a new candidate aware with greening.

In order to create environmental awareness among all hotel members in all management levels as well as to improve the required knowledge and skills, hotels should provide an environmental training for new and existing employees Therefore, North (1997) stated that there are many benefits of green training such as improving the environmental awareness and achieving a good environmental performance. Training should be conducted by different methods such as seminar, on-job training and workshop. In this respect, Ramnus (2002) declared that designing environmental training programs starting with gap analysis through identifying candidates' 
environmental training needs with a view to provide the environmental skills, knowledge, and attitudes needed to employees.

\section{Green performance appraisal}

Armstrong (2014) defined the green performance appraisal as the process through it the hotel evaluates green work over a set period, provides green feedback, and resets individuals green goals. Therefore, the green appraisal is one of the quality indicators that measuring the actual green performance of employee against the previously established goals.

According to Arulrajah et al., (2015) there are two approaches for green employee performance evaluation; first approach is to be made separately while the second approach is to be a component of the performance appraisal. In that sense, Wehrmeyer (1996) suggested to incorporate organization environmental objectives and targets with the system of the organization performance appraisal. While, Renwick et al., (2013) suggested that the green auditor or the human resource manager should provide a consistent feedback to the organization staff to succeed environmental goals or develop their environmental performance.

\section{Green reward management}

Opatha (2013) argued that green reward management has important contributions to motivate all employees of organization on corporate environmental management initiatives. Renwick et al., (2008) suggested two options for practice the green reward management, the financial and nonfinancial. The organization can be rewarded for the good environmental performance by financially rewards such as incentives, bonuses and cash, while the non-financially rewarded methods included (honors, prizes, awards, special recognitions).

Green reward management practices offer rewards for creative environmental initiative/performance. Moreover, it is required to support various creativity among the employees (Woods, 1993). In that sense, Jackson et al., (2011) suggested to provide incentives to support, re-use, recycling and waste management.

\section{Green employee discipline management}

According to Arulrajah et al., (2016) the green discipline management is highly important in order to ensure green employee behavior inside the organization, to achieve the objectives and strategies of environmental management. Therefore, a clear policy and regulation of environmental sustainability and green practices should be informed to organization employees. Renwick (2008) and Opatha (2013) indicated that the function and practices of green employee discipline management include a progressive 
disciplined regulation to penalize staffs who go against the base of green performance.

\section{Green employee relations}

Renwick et al., (2013) recommended some of green employee relations include employee involvement and participation in green suggestion schemes and problem-solving, developing training courses for the union representatives in environmental management and cooperating with stakeholders in all environmental issues.

\section{Barriers of GHRM}

GHRM such as any new practice has barriers and constrains to apply. In that sense, Likhitkar and Verma (2017) stated that these barriers are the absence of a comprehensive conception of the application of GHRM, the availability of unskilled and unmotivated employees for implementation. Moreover, implementation of green philosophy takes long time, needful a big investment at the beginning of applying, on the other hand, at the same time of the beginning of applying there is a limited achieving considerable return (Hosain and Rahman, 2016).

Deshwal (2015) reported other barriers such as, complexity in recruiting and training the new candidates on GHRM practices, difficulty in performance appraisal of staff behaviors, complexity in shifting employees' attitudes from normal one to green in a short time and the absence of green thinking. Likhitkar and Verma (2017) added that absence of green values is one of the barriers of GHRM. Farid and El-Swalhy (2018) confirmed that lack of awareness's of green practices in managerial level and between organization employees is main barrier for implementation.

Based on literature review, this research suggests the following Hypotheses (Hs)

H1: There is a positive relationship between the dimensions of the GHRM practices.

$\mathrm{H} 2$ : There is a negative relationship between managerial barrier and the practices of GHRM

H3: There is a negative relationship between employees' barrier and the practices of GHRM 


\section{Research Methods}

\section{Study instrument}

The data collection technique was based on a self-administered questionnaire directed to the heads of human resource departments or equivalent positions. The questionnaire aimed to investigate the GHRM practices and barriers of implementation.

The designed questionnaire consisted of four parts. The first part contained the profile of respondents (job position, academic qualification, years of experience, type of hotel management). The second part consisted of five questions about green hotel, the perception and the background that HR managers have about GHRM practices and their application of the GHRM practices in their properties. Moreover, human resource managers were asked about their perceptions about the importance of applying the GHRM. The third part dealt with practices of GHRM in the Egyptian hotels (green planning, green job analysis and design, green recruitment, green induction, training and development, green performance appraisal, green reward management, green employee discipline management, green employee relation). this part also asked respondents to rate the implementation level of green HRM practices. The questionnaires used Five-point likert-type scale ranging where $1=$ very poor, $2=$ poor, $3=$ fair, $4=$ good and $5=$ excellent. The fourth part dealt with barriers of GHRM. Respondents were asked to rate the barriers of GHRM implementation. This is part of questionnaires used Fivepoint likert-type scale ranging from $1=$ strongly disagree, $2=$ disagree, $3=$ not sure, $4=$ agree, $5=$ strongly agree has been used.

The questionnaire was adapted from previous researches on GHRM (Renwick, 2008; Jabbour et al., 2010; Jabbour, 2013; Opatha, 2013; Opatha and Arulrajah, 2014; Mohamed, 2014; Masri, 2016). The questionnaire was fine-tuned through discussions with a sample of human resource managers who working in certified green hotels. It was pilot-tested to verify the validity of the questions being used and to assess the wording of the questions, the continuity and flow, and the length and timing. Thus, a slight change has been made in relation to the wording of.

\section{The Study Sample}

The questionnaire was directed to human resource managers in Red Sea Region, Hurghada. A number of 347 questionnaires was delivered to managers themselves in the selected hotels by the researcher. Each form of questionnaire was supplemented by cover letter explaining the purpose of the research and the importance of the participant's involvement. The cover letter also confirmed the confidentiality and anonymity of data collection. Therefore, no names, and ID numbers were required. Questionnaire forms' distribution took nearly more than three months from the beginning of May 
till the end of August 2019. There 303 forms were valid for analysis, yielding $87.3 \%$ response rate.

With regard to the questionnaire analysis, a Software Package for Social Sciences (SPSS 25) was used. Frequencies were used to analyze the profile of respondents. Descriptive statistics i.e., mean and standard deviation were used to analyze the scale. Pearson correlation was used to test the research hypotheses. The reliability of the measure was assessed using Cronbach's alpha. The instrument yielded an alpha level of $0.94 \%$. In that context, DeVellis (2012) indicates that alpha coefficient should be equal or above 70 . Therefore, this result assures that the instrument of the study is reliable. In other words, the items used in the questionnaire are measuring what it is supposed to measure.

\section{Results and Discussion}

\section{Demographic data analysis}

Table 1 illustrates that the most frequently reported job position was human resource managers $(57.8 \%)$, followed by assistant human resource managers $(24.4 \%)$, followed by other positions, i.e. training managers, greening managers $9.6 \%$. On the other hand, $8.3 \%$ only of the respondents were human resource supervisors. In terms of type of hotel management, table 1 shows that the owner-management $(50.2 \%)$ was slightly higher than the chain hotels $(49.8 \%)$. In addition, most respondents $(81.5 \%)$ were holding bachelor degrees. A ratio of $.3 \%$ only were holding $\mathrm{PhD}$. Since the majority of participants are human managers, therefore $38 \%$ of the respondents have long experience 21 years, followed by $26.1 \%$ have between 10 to 15 years' experience.

\begin{tabular}{|l|l|l|l|}
\hline \multicolumn{3}{|l|}{ Table 1: Analysis of demographic profile } \\
\hline Demographic data & H.R manager & Frequency & Percentage \\
\hline \multirow{4}{*}{ Position } & Ass. H.R manager & 175 & 57.8 \\
\cline { 2 - 4 } & H.R supervisor & 74 & 24.4 \\
\cline { 2 - 4 } & Other & 25 & 8.3 \\
\hline \multirow{3}{*}{$\begin{array}{l}\text { Type of hotel } \\
\text { management }\end{array}$} & Chain & 29 & 9.6 \\
\cline { 2 - 4 } & Owner - management & 151 & 49.8 \\
\hline Education & Bachelor & 152 & 50.2 \\
\cline { 2 - 4 } & Postgraduates & 247 & 81.5 \\
\cline { 2 - 4 } & Master degree & 23 & 7.6 \\
\cline { 2 - 4 } & PhD degree & 14 & 4.6 \\
\cline { 2 - 4 } & Other & 9 & 3 \\
\hline \multirow{5}{*}{ Experience } & Less tha 10 yeras & 10 & 3.3 \\
\cline { 2 - 4 } & $10-15$ Years & 64 & 21.1 \\
\cline { 2 - 4 } & $16-20$ Years & 79 & 26.1 \\
\cline { 2 - 4 } & More than 21 years & 115 & 38 \\
\hline
\end{tabular}




\section{Importance of GHRM}

Table 2 shows that the majority of hotels participants were not classified as green hotels $(88.4 \%)$. On the other hand, only $11.6 \%$ were classified as green hotels. Therefore, most of participants did not have a good understanding of GHRM practices $(70.6 \%)$, while only $29.4 \%$ have a good perception about GHRM practices. Similarly, in terms of applying the practices of GHRM, it is note that the majority of hotels did not apply the practices of GHRM (85.5\%). On contrary, $14.5 \%$ of respondents applied the practices of GHRM. However, $38 \%$ of participants strongly agreed that applying GHRM practices is important, followed by $32.2 \%$ of participants agreed. Only $5.6 \%$ strongly disagreed about the importance of GHRM practices.

\begin{tabular}{|l|l|l|l|}
\hline \multicolumn{3}{|l|}{ Table 2: Analysis of green hotels and GHRM } \\
\hline \multicolumn{3}{|l|}{$\mid$} \\
\hline \multirow{2}{*}{$\begin{array}{l}\text { Hotel classifications (green hotel } \\
\text { or non-green) }\end{array}$} & Yes & Frequency & Percentage \\
\cline { 2 - 4 } & No & 35 & 11.6 \\
\hline \multirow{2}{*}{$\begin{array}{l}\text { Perception of green human } \\
\text { resource management practices }\end{array}$} & Yes & 268 & 88.4 \\
\cline { 2 - 4 } $\begin{array}{l}\text { Applying the green human } \\
\text { resource management practices }\end{array}$ & No & 214 & 29.4 \\
\cline { 2 - 4 } $\begin{array}{l}\text { The importance of green human } \\
\text { resource management }\end{array}$ & No & 44 & 70.6 \\
\cline { 2 - 4 } & Strongly agree & 115 & 14.5 \\
\cline { 2 - 4 } & Ngree & 98 & 38 \\
\cline { 2 - 4 } & Neutral disagree & 39 & 32.3 \\
\cline { 2 - 4 } & Disagree & 34 & 12.9 \\
\cline { 2 - 4 } & Strongly Agree & 17 & 5.6 \\
\hline
\end{tabular}

\section{Practices of GHRM in Red Sea resort}

Table 3 shows that the criterium of planning GHRM has the highest mean score of $(M=2.07, S D$ 0.95). These results indicate that there is an applying of GHRM planning practices, however relatively limited. This was followed by criterium of green performance appraisal total average scale with a mean score of $(\mathrm{M}=1.98, \mathrm{SD}=0.99)$, these figures confirm that there was an application of green performance appraisal, but relatively low. The green employee relations total average scale with a mean score of $(\mathrm{M}=1.97$, $\mathrm{SD}=0.86$ ). These results illustrate that these practices were not applied. This was followed by green employee discipline management total average scale with a mean score of $(\mathrm{M}=1.95, \mathrm{SD}=0.91)$. 


\begin{tabular}{|c|c|c|}
\hline \multicolumn{3}{|l|}{ Table 3: Practices of GHRM in red sea resort } \\
\hline & Mean & $\mathrm{SD}$ \\
\hline \multicolumn{3}{|l|}{ 1. Planning for GHRM } \\
\hline $\begin{array}{l}\text { Hotels have green plan to obtains and retains quantity and quality of } \\
\text { candidates needed to achieve its environment goals }\end{array}$ & 2.03 & .99 \\
\hline Hotels have a plan to preserve the energy and environment & 2.34 & .98 \\
\hline \multirow[t]{2}{*}{$\begin{array}{l}\text { Hotels have a workforce plan to deal with expected requirements of } \\
\text { future environmental business }\end{array}$} & 1.84 & .88 \\
\hline & 2.07 & .95 \\
\hline \multicolumn{3}{|l|}{ 2. Green job analysis and design } \\
\hline Job specification includes green competencies & 1.70 & .89 \\
\hline Hotel have a specific position related to environmental practices & 1.90 & 1.18 \\
\hline The hotel jobs have related environmental tasks & 1.79 & 1.10 \\
\hline \multirow[t]{2}{*}{ Hotel have a green team under supervision of HR } & 2.00 & 1.14 \\
\hline & 1.85 & .97 \\
\hline \multicolumn{3}{|l|}{ 3. Green recruitment and selections } \\
\hline $\begin{array}{lcccc}\begin{array}{l}\text { Recruitment } \\
\text { behavior/commitment criteria }\end{array} & \text { posts } & \text { contain } & \text { environmental } \\
\end{array}$ & 1.50 & .76 \\
\hline Recruitment policy reflects hotel environmental policy and strategies & 1.57 & .68 \\
\hline $\begin{array}{l}\text { When interviewing employees or evaluating them for selection, there } \\
\text { are a questions environment-related }\end{array}$ & 1.57 & .79 \\
\hline \multirow[t]{2}{*}{$\begin{array}{l}\text { The hotel selects candidates who are adequately aware of greening to } \\
\text { fill job vacancies. }\end{array}$} & 1.47 & .68 \\
\hline & 1.53 & .57 \\
\hline \multicolumn{3}{|l|}{ 4. Green induction, training and development } \\
\hline The hotel provides a job specific green induction & 1.56 & .82 \\
\hline The hotel provides training to environmentally friendly best practices & 1.91 & 1.24 \\
\hline The hotel provides environmental education to the employees. & 2.09 & .98 \\
\hline $\begin{array}{l}\text { The hotel identifying environmental training needs of candidates for } \\
\text { make them more environmental concerned. }\end{array}$ & 2.12 & 1.20 \\
\hline $\begin{array}{l}\text { The hotel cascading and improving the right knowledge and skills } \\
\text { about greening (by designing an exclusive training program for } \\
\text { greening). }\end{array}$ & 2.07 & 1.11 \\
\hline \multirow[t]{2}{*}{$\begin{array}{l}\text { The hotel offering an online training material for staff to reduce } \\
\text { training cost }\end{array}$} & 1.61 & .79 \\
\hline & 1.89 & .89 \\
\hline \multicolumn{3}{|l|}{ 5. Green performance appraisal } \\
\hline Employees are aware with green targets, goals and responsibilities & 2.05 & .96 \\
\hline $\begin{array}{l}\text { Employee appraisal including staff contributions to environmental } \\
\text { management }\end{array}$ & 1.79 & .94 \\
\hline $\begin{array}{l}\text { There is a regular feedback to the employees or teams to achieve } \\
\text { environmental goals }\end{array}$ & 2.02 & .93 \\
\hline \multicolumn{3}{|l|}{ (Continued) } \\
\hline
\end{tabular}


Table 3: Practices of GHRM in red sea resort (Continued)

\begin{tabular}{|c|c|c|}
\hline Establishing environmental management information system (EMIS) & 2.02 & 1.27 \\
\hline There is an environmental audit. & 2.12 & 1.29 \\
\hline Green criteria are integrating in employee's job performance appraisal & 1.84 & 1 \\
\hline \multirow[t]{2}{*}{ Installing corporate-wide environmental performance standards. } & 2 & 1.13 \\
\hline & 1.98 & .99 \\
\hline \multicolumn{3}{|l|}{ 6. Green reward management } \\
\hline Hotel rewards employee for environmental performance & 1.90 & .83 \\
\hline $\begin{array}{l}\text { Hotel offers a financially and /or non-financially rewarding for } \\
\text { employee good environmental performance }\end{array}$ & 1.90 & .85 \\
\hline Team excellence awards for better environmental performance & 1.86 & .81 \\
\hline $\begin{array}{lllll}\text { Introducing } & \text { rewards } & \text { for } & \text { innovative } & \text { environmental } \\
\text { initiative/performance } & & & \end{array}$ & 2.11 & 1.20 \\
\hline \multirow[t]{2}{*}{ The hotel rewards green skills acquirement } & 1.92 & .83 \\
\hline & 1.94 & .83 \\
\hline \multicolumn{3}{|l|}{ 7. Green employee discipline management } \\
\hline $\begin{array}{l}\text { There are punishments for noncompliance on targets in environmental } \\
\text { management. }\end{array}$ & 1.93 & .89 \\
\hline $\begin{array}{l}\text { There is disciplinary system to penalize staff who go against the } \\
\text { procedures of green policy. }\end{array}$ & 1.93 & .89 \\
\hline \multirow[t]{2}{*}{$\begin{array}{l}\text { Implementing discipline management as a tool to self-regulate } \\
\text { employees in environmental protection activities of the hotel }\end{array}$} & 2.0 & 1.67 \\
\hline & 1.95 & .91 \\
\hline \multicolumn{3}{|l|}{ 8. Green employee relations } \\
\hline $\begin{array}{l}\text { The hotel provides opportunities to their employees to engage and } \\
\text { participate in green plan and suggestion }\end{array}$ & 1.86 & .82 \\
\hline Employees share in environmental initiatives or programs. & 1.86 & .81 \\
\hline $\begin{array}{l}\text { There is a consultation with employees in solving environmental } \\
\text { problems of the hotel. }\end{array}$ & 2.02 & .97 \\
\hline \multirow[t]{2}{*}{$\begin{array}{l}\text { The hotel provides training to the union representatives in } \\
\text { environmental management }\end{array}$} & 2.12 & 1.20 \\
\hline & 1.97 & .86 \\
\hline
\end{tabular}

Note: scale range: from " $1=$ strongly disagree" to " $5=$ strongly agree"

On the other hand, criterium of green recruitment and selections is the lowest total average scale with a mean score of (1.53, SD.57). These results confirm that green recruitment and selections were not applied. While criterium of green job analysis and design was total average scale with a mean score of $(\mathrm{M}=1.85$, SD 0.97). These results confirmed that practices of green job analysis and design were not applied too. Moreover, statement of green induction, training and development with total average scale a mean score of $(\mathrm{M}=1.89, \mathrm{SD}=0.89)$. These results confirmed that criteria of green induction, training and development were not applied. To that end, the results of table 3 confirm that resorts of Red Sea region, Hurghada town, did not full adopt the GHRM practices 


\section{Barriers of applying GHRM practices}

Managerial barriers consisted of 11 items. The results in Table 4 show that statement "lack of awareness of green practices" has the highest mean score of $M=3.97$, SD.91. This is in line with the studies of El-swalhy and Faried (2018) who confirmed that the lack of awareness of green practices is the main barrier for implementation. Followed by "lack of green culture" that has a mean score of $\mathrm{M}=3.78, \mathrm{SD}=.78$. This is followed by "lack of GHRM awareness and knowledge" with a mean score of $\mathrm{M}=3.77, \mathrm{SD}=.82$. This is consistent with thestudies of Likhitkar and Verma (2017).

On contrary, the lowest mean score criteria were, "lack of organizational leadership support for GHRM practices" $(\mathrm{M}=3.19, \mathrm{SD}=1.15)$. This is followed by "complexity of attracting green employees" $(\mathrm{M}=3.32, \mathrm{SD}=1.12)$. Similarly, criterium of "difficulty in process of green recruiting and training employees on GHRM practices" $(\mathrm{M}=3.31, \mathrm{SD}=1.12)$. This result agrees with that reported by Deshwal (2015) who mentioned that there is a difficulty in attracting a green employee for the property.

In terms of employee barriers, the results indicate that the average scale with a mean score of $(\mathrm{M}=3.7, \mathrm{SD}=.86)$ for employee barrier is higher than the overall mean score of managerial barriers $(\mathrm{M}=3.52 . \mathrm{SD}=.99)$. In addition to the highest statement mean is "insufficient awareness of the concept of environmental sustainability" ( $\mathrm{M}=3.81, \mathrm{SD}=.82)$, followed by "difficulty of changing the culture of the current staff" staff resistance" $(\mathrm{M}=3.77, \mathrm{SD}=.90)$. This is consists with the studies of Hosain and Rahman (2016) and Cheema et al., (2015). On the other hand, statement of "lack of qualified and motivated employees" is the lowest mean score $(\mathrm{M}=3.21, \mathrm{SD}=.96)$. This is in agreement with the studies of Cheema et al., (2015)

\begin{tabular}{|c|c|c|}
\hline & Mean & $\mathrm{SD}$ \\
\hline \multicolumn{3}{|l|}{ 1. Managerial barriers } \\
\hline Lack of organizational leadership support for GHRM practices & 3.19 & 1.15 \\
\hline The high cost of applying green practices & 3.58 & .97 \\
\hline The lack of a comprehensive plan to implement GHRM & 3.33 & 1.14 \\
\hline Lack of awareness's of green practices & 3.97 & .91 \\
\hline Lack of green culture & 3.78 & .78 \\
\hline Complexity of attracting green employees & 3.32 & 1.12 \\
\hline $\begin{array}{l}\text { Difficulty in process of green recruiting and training employees on } \\
\text { GHRM practices }\end{array}$ & 3.31 & 1.12 \\
\hline Complexity in performance evaluation of employees' behaviors & 3.39 & .99 \\
\hline Lack of employees' engagement in environmental practices & 3.71 & .85 \\
\hline Lack of green HRM awareness and knowledge & 3.77 & .82 \\
\hline (Continued) & & \\
\hline
\end{tabular}


E. Sobaih, A

\begin{tabular}{|c|c|c|}
\hline \multirow[t]{2}{*}{ Lack of technical support for environmental practices } & 3.64 & 1.01 \\
\hline & 3.52 & .99 \\
\hline \multicolumn{3}{|l|}{ 2. Barrier related to employees } \\
\hline Insufficient awareness of the concept of environmental sustainability. & 3.81 & .82 \\
\hline Lack of qualified and motivated employees & 3.21 & .96 \\
\hline $\begin{array}{l}\text { Staff attitudes and difficulty to change from traditional to GHRM " } \\
\text { staff resistance" }\end{array}$ & 3.77 & .90 \\
\hline \multirow[t]{2}{*}{$\begin{array}{l}\text { Green management initiatives require new jobs and skills and these is } \\
\text { not available }\end{array}$} & 3.39 & .76 \\
\hline & 3.7 & .86 \\
\hline
\end{tabular}

\section{Testing Research Hypotheses}

\section{a. The relationship between green HRM practices}

The correlation analysis was conducted to illustrate the relationship between the criteria of GHRM as well as the relationship between the GHRM practices and the barrier of implementation. Table (5) indicates that there was a strong relationship between the planning of green human resource and all of GHRM practices except the recruitment and selection was a medium relationship ( $\mathrm{r}, .55, \mathrm{P}<.001)$. Moreover, criteria of job analysis and design have a strong relationship with other GHRM practices except the term of recruitment and selection was a medium relationship ( $\mathrm{r}, .68, \mathrm{P}<.001)$. While term of recruitment and selection has a medium relationship with all of GHRM practices, except the relationship with term of induction, training and development was strong $(r, .71, \mathrm{P}<.001)$. 
Table 5: The relationship between green HRM practices and Barriers

\begin{tabular}{|c|c|c|c|c|c|c|c|c|c|c|c|}
\hline & & 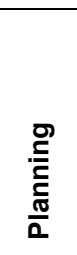 & 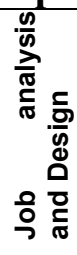 & 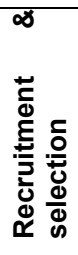 & 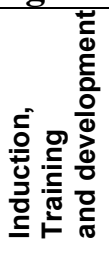 & 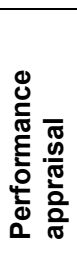 & 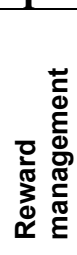 & 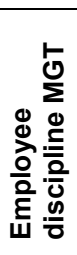 & 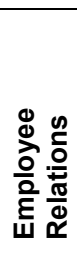 & 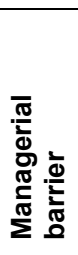 & 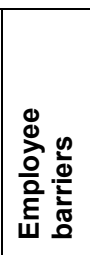 \\
\hline \multirow[t]{2}{*}{$\begin{array}{l}\text { Job analysis } \\
\text { and Design }\end{array}$} & $\begin{array}{l}\text { Pearson } \\
\text { Correlation }\end{array}$ & .797 & & & & & & & & & \\
\hline & $\begin{array}{l}\text { Sig. } \\
\text { tailed) }\end{array}$ & .000 & & & & & & & & & \\
\hline \multirow[t]{2}{*}{$\begin{array}{l}\text { Recruitment and } \\
\text { selection }\end{array}$} & $\begin{array}{l}\text { Pearson } \\
\text { Correlation }\end{array}$ & $.544^{\circ}$ & $679^{\circ}$ & & & & & & & & \\
\hline & $\begin{array}{ll}\text { Sig. } & (2- \\
\text { tailed) }\end{array}$ & .000 & .000 & & & & & & & & \\
\hline \multirow[t]{2}{*}{$\begin{array}{l}\text { Induction, Training } \\
\text { and development }\end{array}$} & $\begin{array}{l}\text { Pearson } \\
\text { Correlation }\end{array}$ & $748^{\circ}$ & 904 & .709 & & & & & & & \\
\hline & $\begin{array}{ll}\text { Sig. } & (2- \\
\text { tailed) }\end{array}$ & .000 & .000 & .000 & & & & & & & \\
\hline \multirow[t]{2}{*}{$\begin{array}{l}\text { Performance } \\
\text { appraisal }\end{array}$} & $\begin{array}{l}\text { Pearson } \\
\text { Correlation }\end{array}$ & $.759^{*}$ & $.914^{*}$ & $.662^{*}$ & $.956^{* *}$ & & & & & & \\
\hline & $\begin{array}{ll}\text { Sig. } \\
\text { tailed })\end{array}$ & .000 & .000 & .000 & .000 & & & & & & \\
\hline \multirow[t]{2}{*}{$\begin{array}{l}\text { Reward } \\
\text { management }\end{array}$} & $\begin{array}{l}\text { Pearson } \\
\text { Correlation }\end{array}$ & $.711^{*}$ & $.833^{*}$ & $.575^{*}$ & $.864 "$ & $.915^{*}$ & & & & & \\
\hline & $\begin{array}{ll}\begin{array}{l}\text { Sig. } \\
\text { tailed) }\end{array} & (2- \\
\end{array}$ & .000 & .000 & .000 & .000 & .000 & & & & & \\
\hline \multirow{2}{*}{$\begin{array}{l}\text { Employee } \\
\text { discipline } \\
\text { Management }\end{array}$} & $\begin{array}{l}\text { Pearson } \\
\text { Correlation }\end{array}$ & $.725^{*}$ & $.855^{*}$ & $.599^{*}$ & $.893^{* * *}$ & $.927^{*}$ & $930^{*}$ & & & & \\
\hline & $\begin{array}{ll}\begin{array}{l}\text { Sig. } \\
\text { tailed })\end{array} & (2- \\
\end{array}$ & .000 & .000 & .000 & .000 & .000 & .000 & & & & \\
\hline \multirow[t]{2}{*}{$\begin{array}{l}\text { Employee } \\
\text { Relations }\end{array}$} & $\begin{array}{l}\text { Pearson } \\
\text { Correlation }\end{array}$ & $.703^{\circ}$ & $834^{\circ}$ & 613 & $.899^{\prime \prime \prime}$ & 907 & 948 & $911^{\circ}$ & & & \\
\hline & $\begin{array}{l}\text { Sig. } \\
\text { tailed) }\end{array}$ & .000 & .000 & .000 & .000 & .000 & .000 & .000 & & & \\
\hline \multirow[t]{2}{*}{$\begin{array}{l}\text { Managerial } \\
\text { barriers }\end{array}$} & $\begin{array}{l}\text { Pearson } \\
\text { Correlation }\end{array}$ & $\begin{array}{l}- \\
.512 \\
-.+\end{array}$ & $\begin{array}{l}- \\
.640 \\
-\end{array}$ & $\begin{array}{l}- \\
.446 \\
- \\
-\end{array}$ & $-.666-"$ & $\begin{array}{l}- \\
.671 \\
--_{* *}\end{array}$ & $\begin{array}{l}- \\
.652 \\
- \\
-\end{array}$ & $\begin{array}{l}- \\
.651 \\
-.+\end{array}$ & $\begin{array}{l}- \\
.664 \\
- \\
-\end{array}$ & & \\
\hline & $\begin{array}{l}\text { Sig. } \\
\text { tailed) }\end{array}$ & .000 & .000 & .000 & .000 & .000 & .000 & .000 & .000 & & \\
\hline \multirow[t]{2}{*}{$\begin{array}{l}\text { Employee } \\
\text { barriers }\end{array}$} & $\begin{array}{l}\text { Pearson } \\
\text { Correlation }\end{array}$ & $\begin{array}{l}- \\
.286 \\
-*\end{array}$ & $\begin{array}{l}- \\
.423 \\
-\end{array}$ & $\begin{array}{l}- \\
.278 \\
--^{* *}\end{array}$ & $-.434-{ }^{* *}$ & $\begin{array}{l}- \\
.443 \\
-.+\end{array}$ & $\begin{array}{l}- \\
.420 \\
- \\
-\end{array}$ & $\begin{array}{l}- \\
.437 \\
-.+\end{array}$ & $\begin{array}{l}- \\
.413 \\
- \\
-\end{array}$ & $.662^{*}$ & \\
\hline & $\begin{array}{l}\text { Sig. } \\
\text { tailed) }\end{array}$ & .000 & .000 & .000 & .000 & .000 & .000 & .000 & .000 & .000 & \\
\hline
\end{tabular}

** . Correlation is significant at the 0.01 level (2-tailed)

The results also illustrate that terms of induction, training and development has a strong relationship with all of the GHRM practices without exceptions. Similar results for the practices of performance appraisal, reward management, discipline management and employee relation have a strong 
relationship with other GHRM practice. This illustrates there was a positive relationship between the dimensions of green human practices. So, the first hypothesis (H1) "There is a positive relationship between the dimensions of the green human resource practices" is accepted.

\section{b. The relationship between managerial barriers and GHRM practices}

The results in table 5 shows that there was a medium negative relationship between managerial barriers and all the practices of green human resource management. Therefore, the second hypothesis (H2) "There is a negative relationship between managerial barrier and the practices of GHRM "is accepted.

\section{c. The relationship between employee barriers and GHRM practices}

Table 5 illustrate that there was a weak negative relationship between employee barriers and two of GHRM practices including planning ( $r, .29$, $\mathrm{P}<.001)$, recruitment and selection $(\mathrm{r}, .28, \mathrm{P}<.001)$. Moreover, there was a medium relationship between employee barrier and practices of job analysis and design, induction, training and development, performance appraisal, reward management, employee discipline management and employee relation. Therefore, the third hypothesis (H3) "There is a negative relationship between employee's barrier and the practices of GHRM "is accepted. Results also indicate that there was a medium relationship between managerial barrier and employee barrier $(r, 66, \mathrm{P}<.001)$.

\section{Conclusion and Recommendation}

Human resource is the most important asset of hotel that plays a key role in managing the hotel staff. Currently, the recent increased trend of corporate focus on greening the business, the contemporary human resource managers have been assigned with additional HRM responsibility of incorporating the green policy to the traditional practices. The GHRM practices include planning, job analysis and design, recruitment and selection, training and development, performance appraisal, rewards management and employee relations.

Green organizations have several practices and gaining advantages by applying the GHRM such as: maximizing the profitability by reducing wastes, recycling and reuses of materials, enhancing the property image, attracting and retaining green customers, reducing the negative environmental effect and better financial performance and good hotel reputation in the market. Moreover, hotel employees also are gaining many benefits based on GHRM practices such as reducing staff turnover, increasing creativity and 
innovation and improving the relationships between hotel and their employees.

This research investigated adoption level of GHRM practices and the implementation barriers in the Egyptian hotels. In order to achieve this aim, a self-administrated questionnaire was distributed to a sample of resorts in Hurghada in Red Sea Region. The results signify that Hurghada Resort do not fully adopt the GHRM policies. The lack of GHRM practices implementation in Hurghada resorts was connected to several barriers shown by the results. These barriers have been divided into managerial barriers and barriers belong to the staff themselves.

The results also show that there was a relationship between the presence of these barriers and the adoption of GHRM practices in hotels. The results illustrated that the more these barriers are found, the lower application of GHRM practices is.

According to the obtained findings, the following recommendations can be suggested in order to fully adopt the greening practices into the traditional human resource practices. The recommendation are as follows:

1. Human resource managers should be involving the green practices into HRM practices; this involvement should include all human resource management functions: planning, job analysis and design, recruitment and selection, induction, training and development, performance appraisal, reward management and employee relation.

2. Practices of GHRM have a negative relationship with barrier of implementation (managerial and employees). Therefore, shifting to green practices requires a cooperation between managerial level and hotel employee to overcome the constrain of implementation.

3. Hotel managers should understand and increase the scope and depth of GHRM practices, organizations can improve their environmental performance in a more sustainable manner than before. 


\section{References}

Armstrong M. (2014). Armstrong's handbook of Human Resource Management Practice, 20th ed., British Library, UK, PP 333-391.

Arulrajah, A., Opatha, H., and Nawaratne, N. (2016). Green human resource management practices: A review. Sri Lankan Journal of Human Resource Management, 5(1), 1-16. doi: 10.4038/sljhrm. v5i1.5624.

Ashraf, F., Ashraf, I., and Anam, W. (2015). Green HR for businesses. International Journal of Academic Research in Business and Social Sciences, 5(8), 149-156.

Ayeswarya, R. (2017). A study on green human resource management practices and its impact on organizations. International Journal of Advanced Research in Management, Architecture, Technology and Engineering, 3(4), 106-113.

Bohdanowicz, P. (2006). Environmental awareness and initiatives in the Swedish and Polish hotel industries e survey results. International Journal of Hospitality Management. 2(5), 662-682.

Bruns-Smith, A., Choy, V., Chong, H., and Verma, R. (2015). Environmental sustainability in the hospitality industry: Best practices, guest participation, and customer satisfaction. Cornell Hospitality Report, 15(3), 6-16.

Cheema, S., Pasha, A., and Javed, F. (2015). Green human resource practices: Implementations and hurdles of SMEs in Pakistan. Journal of Business Studies Quarterly, 7(2), 231-241.

Cherian, J., and Jacob, J. (2012). A study of green HR practices and its effective implementation in the organization: A review. International Journal of Business and Management, 7(21), 25-33.

Daily, F., and Huang, C. (2001). Achieving sustainability through attention to human resource factors in environmental management. International Journal of Operations \& Production Management, 21(12). 1539-1552.

Deepika, S. (2016). Green HRM: An effective tool to attain \& maintain competitive advantage. International Journal of Advanced Research in Engineering \& Management, 2(5), 14-16.

Deshwal, P. (2015). Green HRM: An organizational strategy of greening people. International Journal of Applied Research, 1(13), 176-181.

DeVellis, F. (2012). Scale development: Theory and applications. Los Angeles: Sage. 109-110. 
Dutta, S. (2012). Greening people: A strategic dimension. ZENITH International Journal of Business Economics \& Management Research, 2(2), 143-148.

Erdogan, N., and Baris, E. (2007). Environmental protection programs and conservation practices of hotels in Ankara, Turkey. Tourism Management, 28(2), 604-614.

Farid, M., and El-Swallhu, H. (2018). Green human resource management in hotels: Awareness and implementation. https://www.researchgate.net/publication/32870387.

Fayyazi, M., Shahbazmoradi, S., Afshar, Z., and Shahbazmoradi, M. (2015). Investigating the barriers of the green human resource management implementation in oil Industry. Management Science Letters, 5(1), 101-108. doi: 10.5267/j.msl.2014.12.002.

Garg, B. (2014). Human resource- driving force of sustainable business practices. International Journal of Innovative Research \& Development, 3(7), 378-382.

Gerhart, B., Wright, M., McMahan, C., and Snell, A. (2000), Measurement Error in Research on Human Resources and Firm Performance: How Much Error is There and How Does It Influence Effect Size Estimates, Personnel Psychology, 53 (4), 803-834.

Gössling, S., Peeters, P., Ceron. P., Dubois, G., Patterson, T., and Richardson, B. (2005). The eco-efficiency of tourism. Ecological Economics, 54(4), 417- 434.

Goswami, T., and Ranjan, S. (2015). Green HRM: Approach to sustainability in current scenario. Journal for Studies in Management and Planning, 1(4), 250-259.

Govindarajulu, N., and Daily, F. (2004). Motivating employees for environmental improvement. Industrial Management \& Data Systems, 104, 364-372.

Haden, P., Oyler, D., and Humphrey, H. (2009). Historical, practical, and theoretical perspectives on green management. An Exploratory Analysis Management Decision, 47, 1041-1055.

Hosain, S., and Rahman, S. (2016). Green human resource management: A theoretical overview. IOSR Journal of Business and Management, 18(6), 54-59.

Jabbour, C. (2013). Environmental training in organizations: From a literature review to a framework for future research. Resources, Conservation and Recycling, $74,144-155$.

Jabbour, C., Santos, A., and Nagano, S. (2010). Contributions of HRM throughout the stages of environmental management: Methodological triangulation applied to companies in Brazil. The International Journal of Human Resource Management, 21, 1049-1089.http://dx.doi.org/. 
Jackson, E., Renwick, W., Jabbour, J., and Muller-Camen, M. (2011). State-ofthe-art and future directions for green human resource management: Introduction to the special issue. German Journal of Human Resource Management, 25(2), 99-116.

Jafri, S. (2012). Green HR practices: An empirical study of certain automobile organizations of India. Elixir International Journal of Human Resource Management, 42, 6193-6198.

Javed, F., and Cheema, S. (2017). An empirical investigation on the impacts of the adoption of green HRM in the agricultural industry. Journal of Internet Banking and Commerce, 22(8), 1-14.

Likhitkar, P., and Verma, P. (2017). Impact of green HRM Practices on organization sustainability and employee retention. International Journal for Innovative Research in Multidisciplinary Field, 3(5), 152-157.

Mampra, M. (2013). Green HRM: Does it help to build a competitive service sector? A study. In Proceedings of the tenth AIMS International Conference on Management, Bangalore, India, 1273-1281.

Masri, H. (2016). Assessing Green Human Resources Management Practices in West Bank: An Exploratory Study, Master Thesis, Faculty of Graduate Studies, AnNajah National University.

Mathieson, A., and Wall, G. (1982). Tourism, Economic, Physical and Social Impacts, Longman, London.

Mehta, K., and Chugan, P. (2015). Green HRM in pursuit of environmentally sustainable business. Universal Journal of Industrial and Business Management, 3(3), 74-81.

Mishra, R., Sarkar, S., and Kiranmai, J. (2014) Green HRM: innovative approach in Indian public enterprises. World Review of Science, Technology and Sustainable Development 11(1), 26-42.

Mohamed, H. (2014). Corporate social responsibility in small and medium enterprises: Evidence from tourism sector (Doctoral dissertation). Faculty of Tourism and Hotels, University of Sadat City.

Molina-Azorín, F., Claver-Cortés, E., López-Gamero, D., and Tarí, J. (2009). Green management and financial performance: a literature review. Management Decision, 47(7), 1080-1100. doi:10.1108/00251740910978313.

North, K. (1997), Environmental Business Management - An Introduction, 2nd International Labour Office: Geneva. 
Opatha, H., and Arulrajah, A. (2014). Green human resource management: Simplified general reflections. International Business Research, 7(8), 101-112.

Opatha, P. (2013), Green Human Resource Management: A Simplified Introduction, HR Dialogue, Department of HRM, Faculty of Management Studies and Commerce, University of Sri Jayewardenepura, 22-41.

Owino, W., and Kwasira, J. (2016). Influence of selected green human resource management practices on environmental sustainability at Menengai Oil Refinery Limited Nakuru, Kenya. Journal of Human Resource Management, 4(3), 19-27.

Phillips, L. (2007), Go Green to Gain the Edge over Rivals, People Management, 23rd August, p.9.

Rahman, I., Reynolds, D., and Svaren, S. (2012). How "green" are North American hotels? An exploration of low-cost adoption practices. International Hospitality Management, 31, 720-727. doi: 10.1016/j.ijhm.2011.09.008.

Ramnus, A. (2002). Encouraging innovative environmental actions: What companies and managers must do. Journal of World Business, 37, 151-164.

Renwick, D. (2008). Green HRM: A review, process model, and research agenda (Discussion Paper Series). The University of Sheffield.

Renwick, W., Jabbour, J., Muller-Camen, M., Redman, T., and Wilkinson, A. (2015). Contemporary developments in Green (environmental) HRM scholarship. International Journal of Human Resource Management, 27(1-2), 114-128.

Renwick, W., Redman, T., Maguire, S. (2013). Green human resource management: A review and research agenda. International Journal of Management Reviews, 15(1), 1-14.

Revill, C. (2000). The Greening of Personnel/Human Resource Management an Assessment, International Journal of Applied HRM, 1(3), 1-30.

Sheopuri, A., and Sheopuri, A. (2015). Green HR practices in the changing workplace. Business Dimensions, 2(1), 13-26.

Ullah, M. (2017). Integrating environmental sustainability into human resources management: A Comprehensive review on green human resources management (Green HRM) practices. Maghreb Review of Economics and Management, 4(1), 622. doi:10.12816/0037717.

Vikneswaran, N., and Anantharajah, S. (2012). A green makeover for our Hotels? Quarterly DOE update on Environment, Development\& Sustainability, (2), 10-12. 
Wehrmeyer, W. (1996). Greening people: Human resources and environmental management. Sheffield: Greenleaf.

Woods, (1993), In Milliman, J., and Clair, J. (1996), "Best Environmental HRM Practices in the USA", In Wehrmeyer, W., (eds), (1996), Greening People - Human Resources and Environmental Management, First Edition, Sheffield, England: Greenleaf Publishing.

Yusoff, Y., Nejati, M., Kee, D., and Amran., A (2018). Linking Green Human Resource Management Practices to Environmental Performance in Hotel Industry. Global business review, 21(3), 1-14.

$$
\text { الملخص العربي }
$$

تواجه صناعة الفنادق العديد من الضغوطات و الدوافع التي أدت إلي تز ايد الإهتمام بالنظم

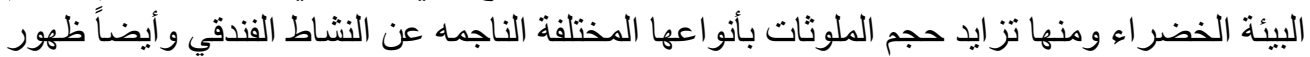

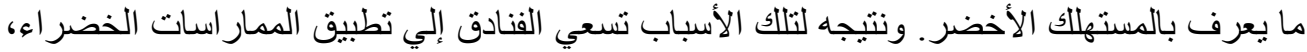

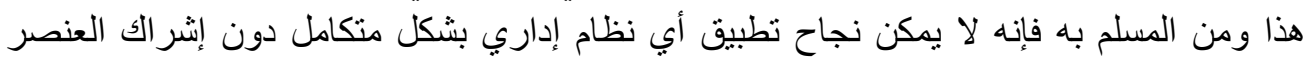

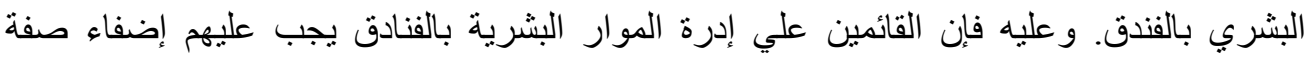

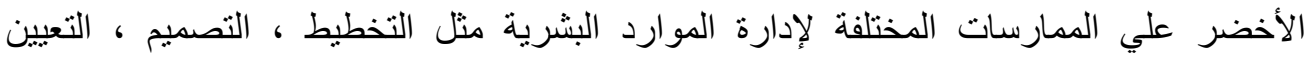

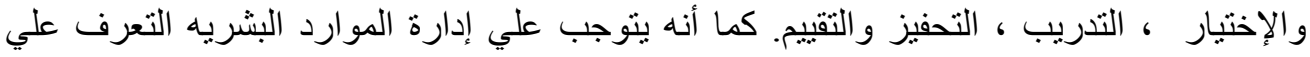

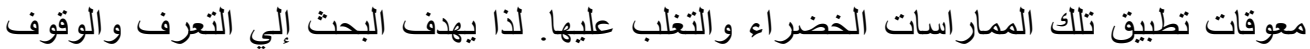

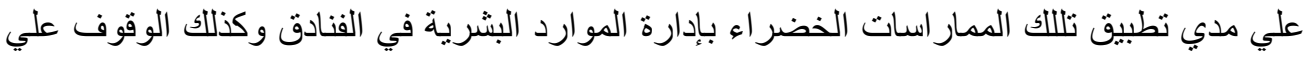

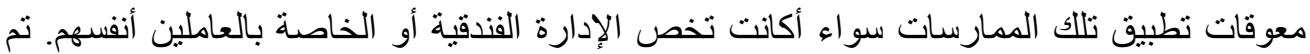

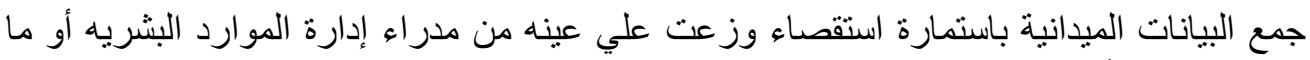

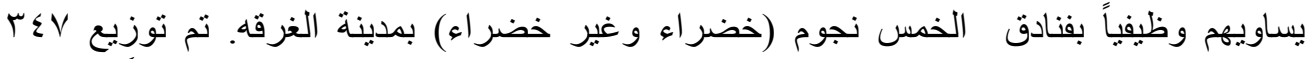

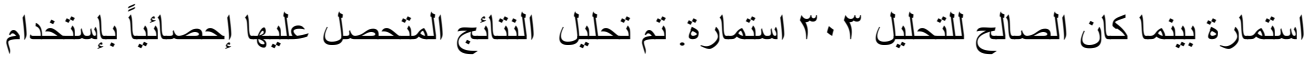

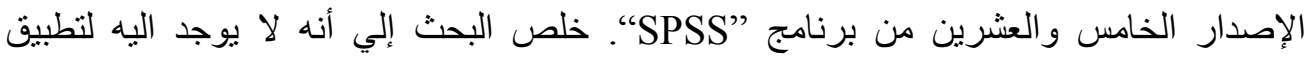

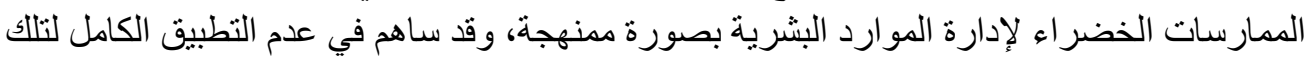

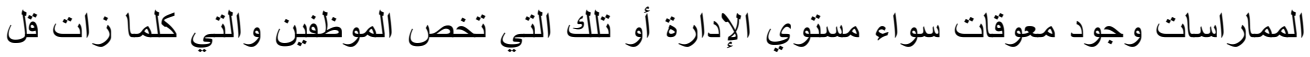

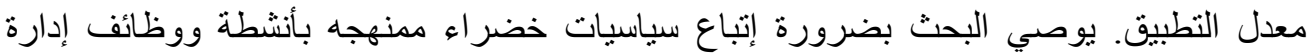

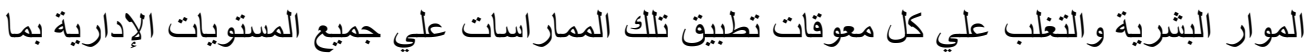

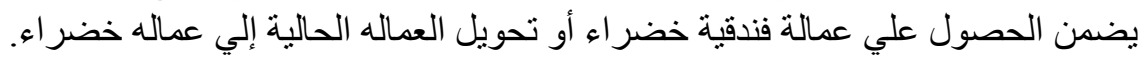

